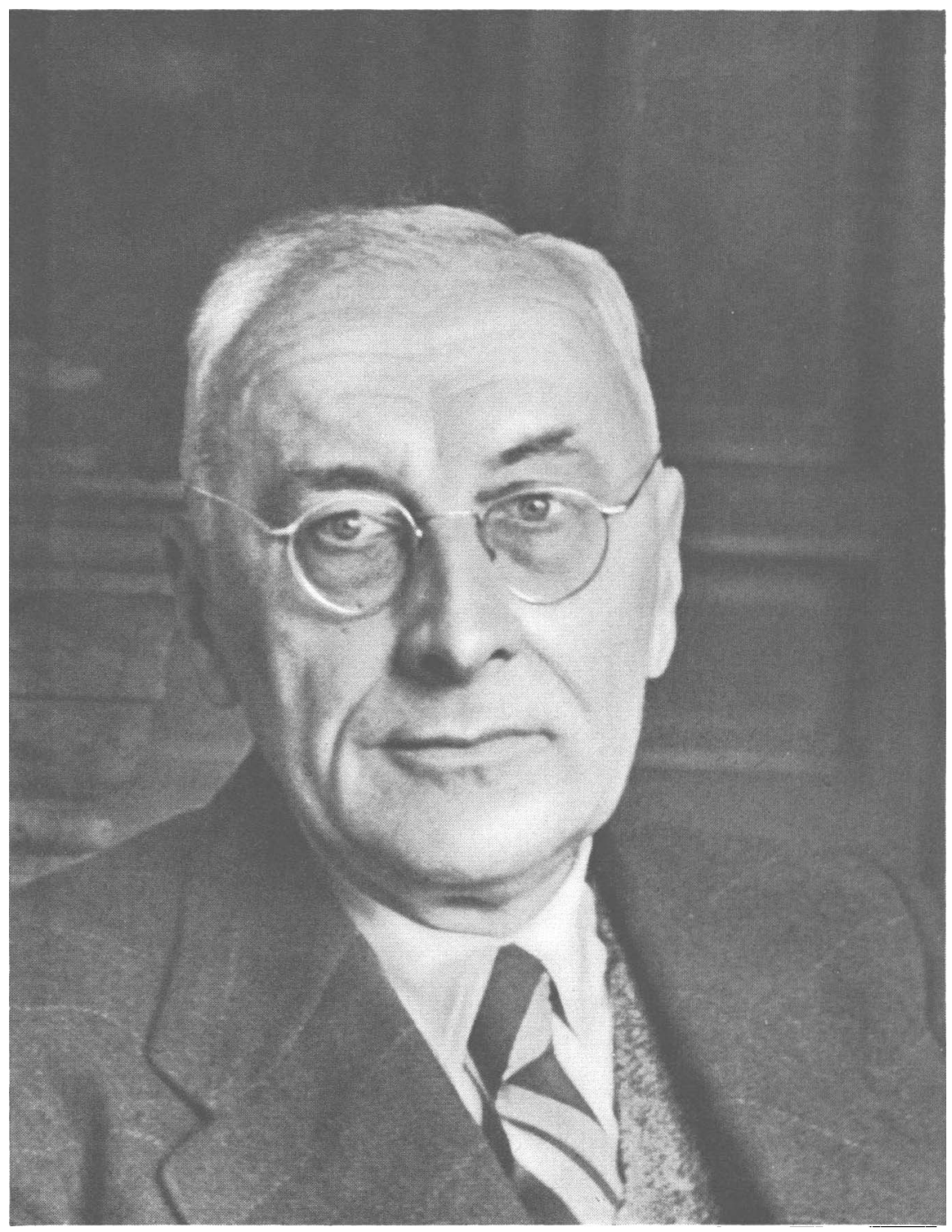

Prof. Mr. N. W. POSTHUMUS 


\section{Prof. Mr. N. W. POSTHumus}

At the close of the year 1952 Professor Mr. N. W. Posthumus retired as director of the International Institute for Social History, a position he had occupied since the foundation of the Institute in 1935, except for the interruption during the years of the German occupation. With his retirement the Institute loses a leader of exceptional ability.

Nicolaas Wilhelmus Posthumus was born on February 26, 1880 in Amsterdam, where he attended gymnasium and studied law and political science at the municipal university. His great interest and activity in social problems was already evident in his student years. In the student society "Clio" he was associated with colleagues who later almost without exception occupied important places in the scientific, political or cultural life of the Netherlands. Most of them were prompted by a great enthusiasm for the socialism which was inspiring many young intellectuals in the first decade of the 20th century. In this context it is characteristic that Posthumus was not completely absorbed in his study and student life, but also diligently applied himself to an investigation of the domestic industry which in these years still possessed a critical form and extent in the Netherlands.

Many careers undoubtedly lay open to Posthumus, but the field of science, particularly historical, finally attracted him. Taking into account his politico-social interest and the general trend of thought of the progressive intellectuals at the time, it is not surprising that economic history captured the attention of Posthumus. Thus, he chose the history of the Leiden cloth industry as the subject of his thesis. That was an extremely fortunate choice. The study of economic history had as yet made no great progress in the Netherlands and boasted of results only in studies of trade and shipping. Now light was cast on the history of the oldest indigenous industry which had played a rôle in both mediaeval and modern times. That light fell also on the social conditions of the proletariat Bulletin VIII 
in a textile city. In 1908 Posthumus received his doctorate with the publishing of the first volume of his "Geschiedenis van de Leidsche lakenindustrie", the second and third volumes of which appeared in 1939. Parallel to this ran a publication of sources in six volumes on the same subject, appearing in the series of Rijks Geschiedkundige Publicatieën.

In the meantime Posthumus had become a teacher in the Handelsschool (Public Trade School) in Amsterdam; his appointment as professor in economic history at the Rotterdamse handelshoogeschool (High School of Economics) followed in 1913 at a very young age. In 1922 he accepted the same position at the University of Amsterdam.

In his years as professor Posthumus became one of the pioneers of economic history in the Netherlands and, most important, an organizer on a big scale in the scientific sphere. He retained his political interest, even though he did not translate it into concrete action. Testifying to his social concern is the Institute for Mature Youth, which he established in Roterdam in order to help develop vagrant youth of the city into useful members of society.

As an historian, Posthumus was primarily the man who broke and prepared the ground for those who came after him. He was more inclined to the collection and publication of sources than to the creation of an historical picture, although he has not entirely neglected the latter. Besides the sources of the Leiden cloth industry, he published the "Documentatie betreffende de buitenlandse handelspolitiek van Nederland in de 19e eeuw", which appeared in six volumes between 1919 and 1931, the "Bescheiden betreffende de provinciale organisatie der Hollandsche lakenbereiders" (1917), and the "Recueil de documents internationaux relatifs à l'histoire économique de 1914-1924" (volume I, 1929). Thereafter, he published studies on the retail trade in the Republic, on the oldest recorded Amsterdam account book, and on the national organization of the cloth merchants in the Republic, while also making many contributions to the Economisch-Historisch Jaarboek. Extensive, finally was his research on the history of prices, the results of which were embodied in his "Inquiry 
into the history of prices in Holland". The first volume of this work appeared in 1948.

However sound and important all this work is -and it is sound and important-the stature of Posthumus shall be finally determined by another facet of his multifarious activity: Posthumus is still more striking and outstanding as the organizer of science than as the publisher of sources and the descriptive historian. In this field he occupies, both nationally and internationally, a pre-eminently prominent position. His essential nature is defined by his organizational talent.

The less striking things are listed first: as a member of the board of the Historical Society, as a member of the national commission for Dutch history, and as secretary of the Royal Academy for Science, Dutch Science owes much to him. As president of the Dutch section of the International Committee of Historical Sciences, he has worked at the same time for international cooperation in the historical sphere.

To his credit, above all, are his important and peculiar creations: the Netherlands Economic-Historical Archives, the Economic-Historical Library, the International Institute of Social History and, finally, the National Institute for War Documentation.

While professor in Rotterdam he had already formed in 1914 the Netherlands Economic-Historical Archives which were established in The Hague and had as its purpose the collecting of old records relating to trade and industry. By the means of this institution a number of merchant records and other collected documents concerning industrial life, so easily lost, are preserved for historical research. Posthumus did not restrict himself, however, to the collection of archive material: he also established source publications for the Netherlands Economic-Historical Archives and published the Economisch-Historisch Jaarboek. With the support of the municipality he later founded in Amsterdam the EconomicHistorical Library where he, ever the collector, compiled a valuable collection, especially of older works.

Then, in the years 1934-1935 when Hitler had seized power in Germany and the aggressive tendencies of nazism were 
becoming clearer, Posthumus turned his activity to the sphere of social history where he perhaps accomplished his most important work of organization. It was no change of front for him, since he had always given attention to social history in connection with his economic-historical research and collecting, but now this attention was intensified.

It was clearer each day during these years that the national-socialistic regime, along with other things formed a threat to the survival of the collections, documents and printed matter of social-historical significance which were in the possession of individuals or institutions in Germany. Some of these collections were already removed outside the country, but what would be the fate of all this valuable material? Posthumus sought means of preserving it and his lucky star or rather his initiative and resourcefulness brought him in contact with the director of the Central Workingmen's Insurance and Deposit Bank, Nehemia de Lieme. The statutes of this bank stipulated that a large part of the emolument should benefit social projects. De Lieme as well as the Board of Directors saw the importance of the cause and they generously furnished the means which were necessary for the establishment of the International Institute of Social History. The Institute was to serve as a place of refuge for the collections which were threatened by growing nationalsocialism.

Feverish activity followed between the years 1935-1940. First, countless German collections were acquired, then following this, according to the further expansion of nationalsocialism, collections from Czechoslovakia and Austria, and Russian collections which were circulating around Europe. The assets were rounded off by French and English collections of documents and printed works. On this basis an Institute was finally organized, which with great industry had assembled its documents, books, brochures and periodicals, all of which were of importance for social history from 1600 to the present. Not to go unmentioned here is the great support which the librarian of the Institutue, Mrs. A. Adama van Scheltema-Kleefstra, offered the director in doing the 
difficult job, sometimes not without danger, of assembling the material.

The arrangement, inventory and cataloguing of the mass of acquisitions may seem like an unprecedented work. Posthumus began publishing the Bulletin of the International Institute of Social History and the International Review of Social History and prepared a voluminous source publication. Moreover, a branch of the Institute was established in Paris.

If one would risk an attempt to demonstrate the importance of the Institute and therefore the work of Posthumus, he would have to print an inventory of the archives and a catalogue of the library of the Institute. But even if that were possible here, it would only illuminate in part his meritorious service. A few names can give, however, some impression: the Institute acquired the Marx-Engels archives, the Nettlau collection, the Rollin library on the French revolution, the Descave Collection on the Commune, the Axelrod archives and the Kashnor collection on English social history.

The war interrupted this sedulous work and spared neither the Institute nor Posthumus. The Institute was closed, the library carried to Germany; because of wise and far-seeing management, the archives were in Oxford and fortunately out of the reach of the occupying powers. Posthumus was dismissed as director of the Institute, of the Netherlands Economic-Historical Archives, of the Economic-Historical Library, and also as professor. His powers of recovery, however, proved unbroken: secretly he did spade work for the establishment of the National Institute for War Documentation, a project which after the liberation was realized by the Dutch government. It proved an excellent apparatus for the collection and development of material related to the wartime history of the Netherlands.

The library of the International Institute of Social History was found again in Germany, but the catalogue had vanished; the archive collections returned from Oxford, but a majority of the old contributors did not return. The building of the Institute had been completely looted and the financial position of the Institute was difficult in the postwar Netherlands. 
Under these circumstances the Institute, properly speaking, had to be built up from the ground again and Posthumus set himself to the task with the steady cooperation of Mrs. A. Adama van Scheltema. The laborious work bore fruit: in $\mathbf{1 9 5 0}$ the publishing of the Bulletin was resumed, in 1951 the Institute was officially re-opened.

Sometimes in the first years after 1945 there was not shown too much comprehension of the difficult position of the Institute. Apparently the above-sketched adversity was not known or it was evidently assumed that a scientific institution could normally function right after the end of the occupation, precisely as if nothing had happened. Posthumus shall undoubtedly be filled with satisfaction that these difficulties were conquered in the last years of his directorship, that the position of the Institute was again consolidated, and that it has now readied itself to climb the mount again and gradually to extend its activity. This last course is the best way in which the Institute can show its gratitude to its founder: with this in mind, then, either a deficiency or even merely a restriction of activity would not be in harmony with his spirit.

A. J. C. Ruiter 